\title{
Penalty kick skill through knee tuck jump exercise and barrier hops exercise
}

\author{
Lingling Usli Wargadinata ${ }^{1 *}$, and Muchamad Ishak \\ ${ }^{1}$ STKIP Pasundan Cimahi, Pendidikan Olahraga, Jln. Permana 32 B Cimahi, West Java
}

\begin{abstract}
Football always attracts society's attention. Unfortunately in practice, at school for example, students have difficulties in mastering penalty kick. This research aimed to know the influence of knee tuck jump exercise towards penalty kick result in football and the influence of barrier hops exercise towards penalty kick result in football. The design of this research is pretest-posttest design. The population taken was the entire students from class XI SMK 3 LPPM-RI Batujajar which consisted of 126 students. Purposive sampling technique was used to determine the sample. Intentionally, the writer chose as many as 30 students who joined football extracurricular as sample then divided them into two groups namely group A (knee tuck jump exercise) and group B (barrier hops exercise). Based on the result, there was significant difference in mean score between pretest and posttest in group A (29.00) than group B (26.00) towards the result of penalty kick in football. The result of compared $t$ from the difference of two results is 4.92 bigger than t table 1.70. Therefore, knee tuck jump exercise gives more significant result than barrier hops exercise towards penalty kick result in football to the students of football extracurricular in SMK 3 LPPM-RI Batujajar.
\end{abstract}

\section{Introduction}

Football is one of famous sports that is played in team. It attracts society's attention start from children to adult. Many clubs that is associated with football for recreation or achievement purposes. Football is a team game that is played by two teams whereas each of team consists of eleven players and one of them is goalkeeper. [1]

A good team consists of players who have teamwork skill, master the basic technique and be able to control the game. There are some basic techniques that must be mastered in football. Basic techniques in playing football such as kicking, shooting, dribbling, stopping, controlling the ball and goal keeping techniques that are adjusted to its function and situation in the field. [2]

Foot is a dominant part of body in doing basic techniques in football. Passing the ball means transfer the ball from one's foot to another player's foot by kicking. [3] Besides, kicking can be used as a technique to score a goal. A player must master kicking technique and develop shooting technique. The player is expected to do shooting and score a goal from various positions in field. [4]

Kicking technique can be executed when the ball come to a standstill or move. Learning kicking technique is not easy. Kicking technique is usually done using arch in order to 
control the ball. Another factor that should be noticed is leg power. Leg power is a power produced by the contraction of leg's muscles in short time. Power is muscles' ability in making maximal strength in fast time. [5] Power as neuromuscular system ability in producing strength as great as possible in the shortest time. [6] It can be said as neuromuscular system ability to cope with resistance by contraction speed as high as possible.

Leg is the foundation of human's body to support human's activities and it has crucial role in in every sport field. The power of leg's muscles is very determining since its function is to swing the leg from back to forward which is done fast in short time. In obtaining fast and tough kick needs power. Power has big influence towards kick's strength and velocity. [7]

Many students especially in SMK 3 LPPM-RI Batujajar lack of mastering penalty kick technique because they have less intensity in learning kicking technique whereas kicking technique is the most basic technique that must be developed. Based on the researcher's observation to the eleventh grade students in SMK 3 LPMM-RI Batujajar, the students still could not do penalty kick well. They tended to kick the ball weakly and slowly. They did not have enough power to do penalty kick.

A big power of leg is needed to produce good kicking technique. To exercise leg's power, plyometric method must be implemented. Barrier Hops (jump using barrier) and knee tuck jump (jump without barrier) can be implemented to increase the power of leg's muscles.

Knee tuck jump is one form of jump exercise which is started with standing position and folding knee's joint. Then, the arms are placed beside the body. After that, the arms are swung up and jump vertically. When jumping vertically, both of thighs almost touch the chest and back to ready position. This is done continually.

Barrier hops is the exercise that is done on goal post or obstacle which has length between $30-90 \mathrm{~cm}$. The barrier is placed in some lines with certain spacing depend on athlete's ability. The barrier will fall if the athlete makes mistake. [8]

To increase the result of penalty kick, the researcher tried to give some exercises that improve students' ability in doing penalty kick such as knee tuck jump and barrier hops. It is hoped that this implementation will increase the result of penalty kick to be stronger, faster and tougher especially to the students of SMK 3 LPPM-RI Batujajar.

\section{Research method}

The method used in this research is experimental method. This method is experimentation to see the result of a learning process. In the other word, experimental research is research which is done by manipulating research object and there is a control. In this research, the researcher reveals the illustration of the influence of knee tuck jump exercise and barrier hops exercise towards penalty kick in football. The design of research is pre test - post test design. The design can be seen in following figure 1 .

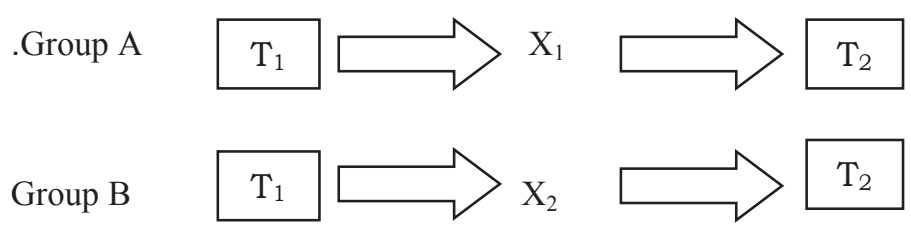

Fig. 1. Research Design [9] 
Note:

T1 : pretest

$\mathrm{X} 1 \quad$ : knee tuck jump exercise

X2 : barrier hops exercise

T2 : posttest

There are two groups of sample. Group A is group which is given knee tuck jump exercise and group B is group which is given barrier hops exercise. The population was the eleventh grade students of SMK 3 LPPM-RI Batujajar that consisted of 126 students. Then, from the population it was chosen as many as 30 students as the sample. The sample was divided into two groups.

The learning process is done three times in a week on Tuesday, Thursday and Saturday for two months. This is based on Sumosardjono $(2009$, p. 12) who said the frequency of exercise must be done at least three times in a week because of one's endurance will decrease after 40 hours if he doesn't do exercise.

\section{Result and discussion}

\subsection{Mean score and standard deviation}

Table 1. The result of mean score and standard deviation calculation

\begin{tabular}{|l|l|c|c|}
\hline Group & Test Period & Mean score & Standard Deviation \\
\hline Group A & Pretest & 22.80 & 2.88 \\
\cline { 2 - 4 } & Posttest & 51.80 & 2.40 \\
\hline \multirow{2}{*}{ Group B } & Pretest & 22.67 & 2.90 \\
\cline { 2 - 4 } & Posttest & 48.67 & 3.18 \\
\hline
\end{tabular}

Based on the table, it can be seen that in group A, the mean score of pretest is 22.80 and the mean score of posttest is 51.80 . Besides, the standard deviation of pretest is 2.88 and the standard deviation of posttest is 2.40. In group B the mean score of pretest is 22.67 and the mean score of posttest is 48.67 . Besides, the standard deviation of pretest is 2.90 and the standard deviation of posttest is 3.18 .

\subsection{Normality test}

Table 2. The result of normality test

\begin{tabular}{|c|l|l|l|l|}
\hline \multirow{2}{*}{ Group } & \multirow{2}{*}{$\begin{array}{c}\text { Test } \\
\text { Period }\end{array}$} & Lo & \multicolumn{1}{|c|}{ L table } & \multirow{2}{*}{ Result } \\
\cline { 4 - 5 } & & & $0.05: 15$ & \\
\hline Group A & Pretest & 0.167 & 0.220 & Normal \\
\cline { 2 - 5 } & Posttest & 0.145 & 0.220 & Normal \\
\hline Group B & Pretest & 0.169 & 0.220 & Normal \\
\cline { 2 - 5 } & Posttest & 0.137 & 0.220 & Normal \\
\hline
\end{tabular}

According to the table, it can be concluded that in group A, it was obtained Lo pretest as many as 0.167 and Lo posttest 0.145 . They are smaller than $\mathrm{L}$ table 0.220 . So, the data of pretest and posttest in group A is normal. Besides, in group B, it was obtained Lo pretest as many as 0.169 and Lo posttest 0.137 . They are smaller than L table 0.220 . So, the data of pretest and posttest in group B is normal. 


\subsection{Homogeneity test}

Table 3. The result of homogeneity test

\begin{tabular}{|c|c|c|l|}
\hline Group & F & F table & \multicolumn{1}{c|}{ Result } \\
\hline Group A & 1.45 & 2.48 & Homogenous \\
\hline Group B & 1.20 & 2.48 & Homogenous \\
\hline
\end{tabular}

From the table, it can be seen that the value of derived $\mathrm{F}$ in group $\mathrm{A}$ is 1.45 and the value of derived $\mathrm{F}$ in group $\mathrm{B}$ is 1.20 . They are smaller than $\mathrm{F}$ table 2.48 which means that the hypothesis is accepted. In other words, the data from pretest and posttest from both of groups are homogenous.

\subsection{Hypotheses test}

Table 4. The calculation of significance increase the study result of group A and group B

\begin{tabular}{|c|c|c|c|c|c|c|}
\hline Group & $\begin{array}{c}\text { Test } \\
\text { Period }\end{array}$ & $\begin{array}{l}\text { Mean } \\
\text { Score }\end{array}$ & $\begin{array}{c}\text { Standard } \\
\text { Deviation }\end{array}$ & $\mathrm{t}$ test & $\begin{array}{c}\mathrm{T} \text { table } \\
0.95(14)\end{array}$ & Result \\
\hline \multirow[t]{2}{*}{ A } & Pretest & 22.80 & \multirow[t]{2}{*}{3.64} & \multirow[t]{2}{*}{30.81} & \multirow[t]{2}{*}{1.76} & \multirow[t]{2}{*}{ Significant } \\
\hline & Posttest & 51.80 & & & & \\
\hline \multicolumn{2}{|c|}{ Difference } & 29.00 & & & & \\
\hline \multirow[t]{2}{*}{ B } & Pretest & 22.67 & \multirow[t]{2}{*}{4.44} & \multirow[t]{2}{*}{22.68} & \multirow[t]{2}{*}{1.76} & \multirow[t]{2}{*}{ Significant } \\
\hline & Posttest & 48.67 & & & & \\
\hline \multicolumn{2}{|c|}{ Difference } & 26.00 & & & & \\
\hline
\end{tabular}

Based on the table above, the value of derived $t$ in group $\mathrm{A}$ is 30.81 bigger than $\mathrm{t}$ table 1.76 which means the implementation of knee tuck jump exercise gives significant influence. Then, the value of derived $t$ in group $B$ is 22.68 bigger than $t$ table 1.76 which means the implementation of barrier hops exercise gives significant influence.

Also, it is found that there is differences in studying result between group A (30.81) and group B (22.68). The value of derived t from group A is bigger than group B (30.81 > 22.68). It means there is more significant increase in study result using knee tuck jump exercise rather than barrier hops exercise in SMK 3 LPPM-RI Batujajar.

Table 5. The calculation of Significance difference the study result of group A and group B

\begin{tabular}{|l|c|c|c|c|c|}
\hline Group & $\begin{array}{c}\text { Mean } \\
\text { score }\end{array}$ & $\begin{array}{c}\text { Standard } \\
\text { deviation }\end{array}$ & T test & T table & Result \\
\hline A & 29.00 & 3.64 & 4.92 & 1.70 & Significant \\
\hline B & 26.00 & 4.44 & & & \\
\hline
\end{tabular}

Based on the table, there is difference in mean score between pretest and posttest that appear significantly in group A which is implemented knee tuck jump exercise (29.00) rather than group B which is implemented barrier hops exercise towards the result of penalty kick in SMK 3 LPPM-RI Batujajar. The calculation of $t$ is 4.92 bigger than $t$ table 1.70. Therefore, the hypothesis is accepted stated knee tuck jump exercise gives more significant result than barrier hops exercise towards penalty kick in football in SMK 3 LPMM-RI Batujajar.

According to data analysis above, it is known that the data from pretest and posttest are normal and homogeneous. Besides, the result from the calculation of pretest and posttest from both of group shows that the implementation of knee tuck jump exercise and barrier hops exercise give significant result. From the calculation of significance difference, it is known that knee tuck jump exercise has more significant influence rather than barrier hops exercise with the value of derived $t 4.92$ bigger than $t$ table 1.70 . 


\section{Conclusion}

Based on the result of research, the conclusions are follows:

4.1 In group A, after being given treatment knee tuck jump exercise as long as two months, there is significant increase towards penalty kick in football to the students of SMK 3 LPMM-RI Batujajar.

4.2 In group B, after being given treatment barrier hops exercise as long as two months, there is significant increase towards penalty kick in football to the students of SMK 3 LPMM-RI Batujajar.

4.3 Group A which was given treatment knee tuck jump exercise gives more significant influence rather than group B which was given treatment barrier hops exercise towards the result of penalty kick in football to the students of SMK 3 LPPM-RI Batujajar with the calculation of $\mathrm{t}$ test 4.92 bigger than t table 1.70 .

\section{References}

1. Sucipto, Sepakbola Latihan dan Strategi, 7 (2005)

2. U. Lingling, Pembelajaran Sepakbola, 36 (2013)

3. Koger, Latihan Dasar Andal Sepakbola Remaja, 19 (2005)

4. Mielke, Dasar-dasar Sepakbola, 67 (2008)

5. H. Awan, Metode Melatih Fisik Pencak Silat, 200 (2006)

6. Persunay, Latihan Kecepatan dan Kekuatan, 2 (2005)

7. Scheunemann, Dasar Sepak Bola Modern, 147 (2012)

8. C. Donald A., Jumping into Plyometric, 40 (2007)

9. Sugiyono, Manajemen Penelitian, 10 (2011) 